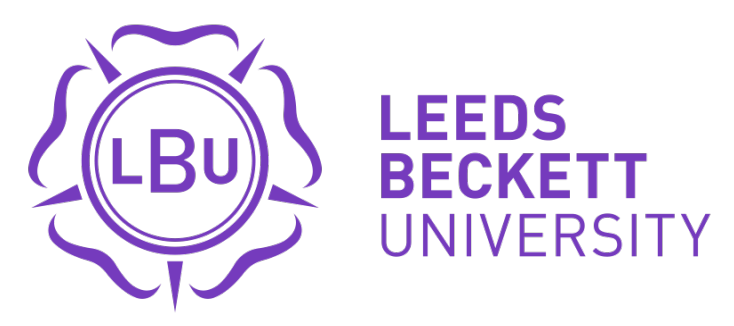

Citation:

Mitchell, $L$ (2018) Re-affirming and rejecting the rescue narrative as an impetus for war: to war for a woman in a Song of Ice and Fire. Law and Humanities. ISSN 1752-1483 DOI: https://doi.org/10.1080/17521483.2018.1514952

Link to Leeds Beckett Repository record:

https://eprints.leedsbeckett.ac.uk/id/eprint/5298/

Document Version:

Article (Accepted Version)

This is an Accepted Manuscript of an article published by Taylor \& Francis in Law and Humanities on 04 September 2018, available online: http://www.tandfonline.com/10.1080/17521483.2018.1514952

The aim of the Leeds Beckett Repository is to provide open access to our research, as required by funder policies and permitted by publishers and copyright law.

The Leeds Beckett repository holds a wide range of publications, each of which has been checked for copyright and the relevant embargo period has been applied by the Research Services team.

We operate on a standard take-down policy. If you are the author or publisher of an output and you would like it removed from the repository, please contact us and we will investigate on a case-by-case basis.

Each thesis in the repository has been cleared where necessary by the author for third party copyright. If you would like a thesis to be removed from the repository or believe there is an issue with copyright, please contact us on openaccess@leedsbeckett.ac.uk and we will investigate on a case-by-case basis. 


\title{
Re-affirming and rejecting the rescue narrative as an impetus for war: To war for a woman in a song of ice and fire
}

\author{
Lynsey Mitchell* \\ Lynsey.mitchell@leedsbeckett.ac.uk
}

\begin{abstract}
From Paris' capture of Helen in Homer's Iliad, and the resulting ten-year war in retaliation, Western literature has a long tradition of narrativising the turn to war as a dispute in service of a woman. Yet in contemporary Western legal accounts it is assumed that legal arch-positivism now governs the decision to go to war, and so any such action can be considered rational and just. However, contemporary turns to war are increasingly invoking just war theory that is wrapped in a similar patriarchal gender narrative. George RR Martin's 'A Song of Ice and Fire' ${ }^{1}$ evokes the European tradition of war in the middle ages, but also explores modern aspects of liberalism, statehood, and international relations. This paper explores how the turn to war is narrativised and understood by various characters in the novels. It does so in order to demonstrate how calls to war rooted in chivalry and protectionism can gain more currency than those rooted in legalist language, but outlines how this then perpetuates and cements a regressive view of women as passive and helpless. This article ultimately calls for an alternative account of law's understanding of war which does not invoke the rescuer paradigm, and so offers potential reimagining of contemporary justifications for war.
\end{abstract}

Keywords: Game of Thrones, Gender; Conflict; Just War; Narratives; Rape, Saving Women

\section{Introduction}

George RR Martin's epic fantasy series 'A Song of Ice and Fire' (ASOIAF) has become a literary sensation. The first book, 'A Game of Thrones' (AGOT) was published with little fanfare in 1997, quickly gaining critical acclaim and cult following among fantasy readers. Martin, who admits to being heavily influenced by Tolkien, initially planned that ASOIAF

\footnotetext{
* The author wishes to thank Professor Julia Shaw for the helpful advice on an early version of this paper, as well as Dr Alan Brown and Dr Jess Guth.

${ }^{1}$ A Song of Ice and Fire is the title of the series of books beginning with 'A Game of Thrones'. HBO adapted the books into the television series 'Game of Thrones'. This article primarily focuses in the material in the novels, but also refers to scenes in the television series. It therefore uses both the title of the books series and the television series interchangeably.
} 
would consist of a trilogy of novels, but has already penned five of an expected seven. The books gained further popularity after the series was adapted into the award-winning HBO television series, 'Game of Thrones'. The novels are celebrated for subverting common fantasy tropes and introducing the genre to mainstream audiences. ${ }^{2}$ What begins in AGOT as a simple historical fantasy morphs into a complex story portraying the deceits and ambitions of the powerful families, and the reader soon realises that many of the narrators are unreliable. The unparalleled detail, and complex plot modelled on actual historical events, such as the War of the Roses, alongside common fantasy themes, have offered a rich tapestry for fans, literary theorists, and wider academic enquiry. ${ }^{3}$

There is an abundance of academic interest in ASOIAF asserting that; 'Martin's fantasy speaks to us because it is a poignant social commentary grounded in sexual/sexist, economic, cultural and political conditions. ${ }^{4}$ As a fantasy novel about war, power, and the machination of feudal politics, it offers a fertile ground for uncovering the conscious and unconscious motivations behind the so called rational impetus for war. As Genz notes: 'The series is laden with sociopolitical themes, including issues of power and gender politics, and it works within a value system based on contemporary Western cultural, political, aesthetic, and economic factors.' 5

Thus, it will be argued that ASOIAF offers a gritty and realistic depiction of war in a pseudomedieval society and also importantly, does not shy away from accurately depicting the suffering caused. This article takes as a starting point, that there are parallels between reality

\footnotetext{
${ }^{2}$ See Ned Vizzini, 'Beyond the Ghetto: How George R.R. Martin Fights the Genre Wars' in James Lowder (ed) Beyond the Wall: Exploring George R.R Martin's A Song of Ice and Fire (Benbella Books 2012). Kustritz writes that "Game of Thrones utilises several specific strategies to distance itself from fantasy's "unrealistic" and feminised fairy tale roots'. Anne Kustritz, "They all Lived Happily Ever After. Obviously": Realism and Utopia in Game of Thrones-Based Alternate Universe Fairy Tale Fan Fiction’ 20165 Humanities 43, at 47.

${ }^{3}$ The TV series has spawned a variety of articles that claim it offers lessons in how to navigate actual political issues, as well as a variety of academic interest. See Stefan Morrone, 'How Game of Thrones teaches us about the Syrian refugee crisis' Institute for Ethics and Emerging Technologies, 3 December 2015; Matthew Taunton, 'Why Game of Thrones is More than Fantasy' New Humanist, 3 June 2015; William Clapton and Laura J. Shepherd, 'Lessons from Westeros: Gender and Power in Game of Thrones' 2017 Politics 37 (1) 5; RC Carpenter, 'Game of Thrones as Theory: It's not as Realist as it Seems- and that's good' Foreign Affairs 29 March 2012; Debra Ferreday, 'Game of Thrones, Rape Culture and Feminist Fandom' 30 (83) Australian Feminist Studies 21; Valerie Estelle Frankel, Women in Game of Thrones: Power, Conformity and Resistance (2014 McFarland and Co); Katie Ellis, 'Cripples, Bastards and Broken Things: Disability in Game of Thrones' (2014) 17 (5) MC Journal; Mat Hardy, 'Game of Tropes: The Orientalist Tradition in the Works of G.R.R. Martin' (2015) 8 (1) International Journal of Arts and Sciences 409.

${ }^{4}$ Stephanie Genz, "I'm not going to Fight Them, I'm Going to Fuck Them": Sexist Liberalism and Gender in A Game of Thrones' in Anne Gjelsvik and Rikke Schubart (eds) Women of Ice and Fire, Gender, Game of Thrones and Multiple Media Engagements (Bloomsbury 2016) at 243.

5 ibid.
} 
and fiction in how power is wielded, ${ }^{6}$ and in particular, how the use of force, or the turn to war, is invoked to justify violence. It draws on a variety of international law and international relations enquiry into popular culture in order to explore ideas about foreign policy, conflict and security. ${ }^{7}$ Such enquiry argues that through popular culture it is possible to explore and identify hidden parallels with the real world and seek alternative methods of understanding power and relationships. ${ }^{8}$ It uses these particular novels because, as Bechky notes, 'it is possible to discern, even in a world where law's impact is notably light, several rules of international law. ${ }^{9}$

According to Wright international law would be meaningless without narrative. ${ }^{10}$ She writes that 'we cannot imagine what we cannot tell as a story'. ${ }^{11}$ Similarly, Husa acknowledges that: 'Literature uses written words, thus creating imaginary worlds and societies which means that imaginary worlds and societies also contain an innate and implicit legal dimension. Accordingly, characters in books hold attitudes and ideas about societal large-scale normativities which we are used to calling law. ${ }^{12}$ Drawing on this growing critique of popular culture to imagine alternative understandings of power dynamics and relations, this article draws a parallel between the narrativisation of going to war in the world of ASOIAF and the imagined world of law.

Despite its classical origins, the story of a woman as the catalyst for war still endures today. Indeed, Chinkin describes how the female image has typically been used 'both to justify the use of armed force and to motivate men to join the armed forces' ${ }^{13}$ Gardam and Jarvis conclude that even today, armed conflict reinforces gender stereotypes that contribute to the subordination of women because these age-old narrative tropes can be used as propaganda for

\footnotetext{
${ }^{6}$ Jameson states that narratives transcend fiction. Fredric Jameson, The Political Unconscious: Narrative as a Socially Symbolic Act (Cornell University Press 1982).

${ }^{7}$ As Clapton and Shepherd note 'disciplinary investigations of global politics and popular culture have a rich and varied history.' Clapton and Shepherd, (n 3), at 8.

${ }^{8}$ John Morrison and Christine Bell (eds) Tall Stories? Reading Law and Literature (Dartmouth 1996); J Weldes, To Seek Out New Worlds: Exploring Links Between Science Fiction and World Politics (Palgrave Macmillan 2003); M Sachleben, World politics on Screen: Understanding International Relations Through Popular Culture (University Press of Kentucky 2014); Laura J. Shepherd, Gender, Violence and Popular Culture: Telling Stories (Routledge 2013).

${ }^{9}$ Perry S Bechky, 'The International Law of Game of Thrones' 67 (1) Alabama Law Review Online 1, at 1.

${ }^{10}$ Shelly Wright, 'The Horizon of Becoming: Culture, Gender and History after September 11' (2002) 71 Nordic Journal of International Law 215, at 233.

11 ibid.

12 Jaakko Husa, 'Exploring Imaginative Legal History: The Legalism of the House Stark in the Game of Thrones' (2015) 20 Media and Arts Law Review 181, at 181.

${ }^{13}$ Christine Chinkin, 'Peace and Force in International Law' (1993) 25 Studies in Transnational Legal Policy 203.
} 
the conflict. ${ }^{14}$ Reports of sexual violence against 'their' women are often a good way to garner popular support for conflict and at the same time highlight the depravity of the enemy. ${ }^{15}$ Kesic states that it is a truism that 'victims of rape will be used to manipulate support for the cause of continuing the fight. ${ }^{16}$ This co-option of the feminine image at once silences women and yet perpetrates the myth that women are being protected by men, ${ }^{17}$ and so galvanises the masculinity, and valorisation, of war. Yet, this image of women as victims is rooted in 'patriarchal notions of women as property and the responsibility of men for protecting their property and taking revenge on those who would pollute this property' ${ }^{18}$ and actually has little to do with, or requires little impetus from, those same women. While feminist scholars make this reasoned argument, some acknowledge that the power of this narrative is such that even they have trouble resisting it. ${ }^{19}$ For instance, even while criticising the masculinisation and gendering of 9/11, Tickner notes that there is "something reassuring about "our men" protecting us from "other men"". ${ }^{20}$ This article explores how such a narrative is cemented early in the first novel, and then ultimately deconstructed. In exposing the fiction underpinning this call to war in ASOIAF, this article ultimately cautions against unfettered adherence to this gendered rescue narrative in contemporary society.

Section 1 outlines the kidnap of Lyanna Stark, the backstory which sets in motion a great war whose consequences will be felt for years to come. It highlights how the story of Lyanna retells the tale of Helen of Troy, arguing that this turn to epic narrative in order to justify war is familiar and accessible, in both literature and in reality. Section 2 then engages with the critical international law scholarship that demonstrates how actual wars come to be understood in

\footnotetext{
${ }^{14}$ Judith Gardam and Michelle Jarvis, Women, Armed Conflict and International Law (Kluwer Law International 2001).

${ }^{15} \mathrm{ibid}$, at 35 .

${ }^{16}$ Obrad Kesic, 'Women and Gender Imagery in Bosnia: Amazons, Sluts, Victims, Witches, and Wombs' (1999) Gender Politics in the Western Balkans: Women and Society in Yugoslavia and the Yugoslav Successor States 187 , at 194.

${ }^{17}$ The narrativisation of war as a chivalrous endeavour for the protection of women is the key focus of this article. Therefore, it is concerned with the narrativisation of 'Robert's Rebellion' and the fallout from this, and draws parallels with modern day conflict. However, it is not intended to suggest that all women in the novels are in need of protection, or that there are not subverted versions of this narrativisation at play. There are several examples of women inhabiting the traditional male role of protector, such as Brienne or Arya, and powerful women who command in their own right, often protecting the men in their charge, such as Daenerys and Asha/Yara. Frankel writes that 'most of the feminism on the show' can be attributed to Daenerys' story arc. Frankel (n 3), at 148. See also Caroline Spector, 'Power and Feminism in Westeros' in Lowder (n 2).

${ }^{18}$ Kesic (n 16), at 198.

${ }^{19}$ Myrttinen and Swaine document how the Foreign and Commonwealth Office subscribes to monster and protector myth. See Henri Myrttinen and Aisling Swaine, 'Monster, Myths, Selfies and Grand Declarations' International Feminist Journal of Politics (2015) 17 (3) 496.

${ }^{20}$ J. Ann Tickner, 'Feminist Perspectives on 9/11' (2002) 3 International Studies Perspectives 333.
} 
public consciousness as altruistic rescue missions abroad, or chivalrous defences of women domestically, and then argues that subverting this narrative would allow for a more appropriate reading of war, which would allow the international legal regime on use of force to operate more honestly. Section 3 outlines the result of promulgating such narratives, namely that it cements the dangerous idea that war can be humanitarian and a tool of liberation, and that it perpetuates the stereotype of women as passive subjects who have no agency of their own. Section 4 offers the inversion of the rescue of Lyanna as a cautionary tale, and suggests that Martin's subversion of this epic narrative provides inspiration for uncovering how wars come to be justified and narrativised today. This article ultimately concludes that the classical heroic narrative still permeates public discourse and provides accessible propaganda that normalises the turn to war. Disrupting and rejecting this narrative would allow for greater debate on the consequences and realities of military violence, thus answering the criticism that international law has instead, all too often, been complicit in violence against women.

\section{To War for a Woman: The 'Kidnap' of Lyanna Stark}

ASOIAF is set in the fictional continent of Westeros and concerns the politics of a state known as the Seven Kingdoms. ${ }^{21}$ The story begins 15 years after a great war in which the ruling dynasty, the Targaryens, have been deposed. King Aerys Targaryen (known as the 'Mad King') and his son (Prince Rhaegar Targaryen) were killed after several noble houses joined forces and went to war at the behest of Lord Robert Baratheon, who is now the reigning king. The first book follows the fortunes of the Stark family, and centres on Eddard Stark (Ned), and his children as they navigate the intrigues of court and the ambitions of the other powerful families. Ned and Robert are old friends and fought together in the war, known as 'Robert's Rebellion'. It is revealed, as the story unfurls, that the impetus for Robert's rebellion was Rhaegar's kidnap of Ned's younger sister Lyanna, to whom Robert was engaged. As Ned's son Bran explains: 'Robert was betrothed to marry her, but Prince Rhaegar carried her off and raped her...Robert fought a war to win her back. He killed Rhaegar on the Trident with his hammer, but Lyanna died and he never got her back at all. ${ }^{22}$ Thus, it is immediately clear that the war is understood as a romantic tragedy which was fought for Lyanna's honour.

\footnotetext{
${ }^{21}$ For an overview of the world of ASOIAF see www.westeros.org and the companion book to the series. George RR Martin, Ellio M Garcia Jr and Linda Antonsson, A World of Ice and Fire: The Untold History of Westeros and the Game of Thrones (Harper Voyager, 2014).

${ }^{22}$ George RR Martin, A Game of Thrones' (Harper Voyager 2003), Bran VII, at 733.
} 
This article analyses the depiction of Lyanna Stark's 'kidnap' which provides the impetus for war. Lyanna's subsequent death provides the key (male) actors with a blank canvas upon which they can narrativise the conflict, and their own actions, as masculinist and heroic, initially as a quest to rescue her, and then ultimately as a cautionary tale of the barbarity of their enemies and how the war was just. Yet, later hints and accounts of Lyanna's conduct begin to challenge the dominant narrative and force the reader to re-evaluate the legality and even the necessity of the war. The hints that Lyanna may have eloped, rather than being kidnapped, call into question the motivations of those who went to war in her name, and offer the reader pause to consider how easy it was to manipulate men to join this cause, which was ostensibly motivated by less altruistic reasons. In the same way, those who wage war today often offer similar justificatory claims to win support for their cause. ${ }^{23}$ The subsequent subversion of the masculinist narrative in the story offers a template for critical international law scholars to provide a more nuanced analysis of the merits of war, rooted in an acceptance that state power is rarely benign towards women. This is in opposition to the dominant narrative, which frequently presents military intervention as a benevolent or altruistic intervention on behalf of oppressed civilians. ${ }^{24}$

The reader is initially given few details of Robert's uprising, except that the kidnap of Lyanna set a series of events in motion that culminated in a fierce battle on the River Trident, where Robert's army defeated the Targaryens and Robert himself killed Rhaegar. Flashbacks outline how, on discovering his sister's kidnap, Lyanna's eldest brother Brandon went to the capital in pursuit of Rhaegar, but was charged with treason by King Aerys. Lyanna's father Lord Rickard Stark was then summoned by the king. The Starks petitioned King Aerys to remedy Rhaegar's slight on Lyanna's honour and ultimately challenged the king to a trial by combat. The king agreed but decreed his champion to be wildfire (a deadly weapon akin to Napalm) and ordered Lord Stark to be roasted alive and his son strangled before the assembled court in the throne room. ${ }^{25}$ Ned therefore inherited the title of Lord Stark, and he and Robert summoned their

\footnotetext{
${ }^{23}$ See Karen Engle, 'Calling in the Troops: The Uneasy Relationship among Women's Rights, Human Rights, and Humanitarian Intervention’ (2007) 20 Harvard Humam Rights Journal 189, at 190.

${ }^{24}$ See Anne Orford, 'Muscular Humanitarianism: Reading the Narratives of the New Interventionism' 10 European Journal of International Law 679; Anne Orford, Reading Humanitarian Intervention: Human Rights and the Use of Force in International Law (Cambridge University Press 2003); David Chandler, From Kosovo to Kabul and Beyond: Human Rights and International Intervention (Pluto 2006); JH Stiehm, 'The Protected, the Protector, the Defender' (1982) 5 Women's Studies International Forum 367; Makau Mutua, 'Savages, Victims, and Saviors: The Metaphor of Human Rights' (2001) 42 Harvard International Law Journal 201.

${ }^{25}$ George RR Martin, A Clash of Kings, (Harper Voyager 2011) Catelyn VII, at 721.
} 
armies and declared war on the Targaryens. ${ }^{26}$ Robert was in love with Lyanna and ostensibly marched to war in order to win her back. At the climax of the year-long war, Robert was injured, but his triumphant army entered the capital to find that Jaime Lannister (a member of the King's private guard) had murdered the king in cold blood. Jaime's father, the powerful Lord Tywin Lannister, entered the capital with his army, and seeking to cement the Lannisters' allegiance to Robert, ordered the murder of Rhaegar's wife and children. Ned set out to rescue his sister, only to find her on her deathbed. ${ }^{27}$

As the story unfolds, the use of various narrators or 'point of view characters' allows the reader to see behind the initial narrative that was presented. It is corroborated that King Aerys was a tyrant who was mistreating his people. ${ }^{28}$ However, the view that Robert is a better king, and that his uprising was a just and chivalrous endeavour, is slowly challenged by various characters, and it is clear that the dominant narrative of the rebellion as told by the victors does not necessarily reflect the truth. The entire conflict comes to be characterised as a heroic and chivalrous quest to redeem Lyanna's honour, with Robert and Ned positioned as honourable men with altruistic intentions. Rosenberg highlights the importance of this narrativisation, noting that Robert invokes the alleged atrocity of Lyanna's kidnap in order to seal the argument that the campaign was just. ${ }^{29}$ There is scant discussion of the fact that the Starks, Baratheons, and other houses rebelled against the Crown and committed treason. Lyanna is certainly given to be the reason for the turn to war, but as the story unfolds it is clear that intrigues and family ambitions played a key role, and the books hint as to whether there was already a plan to declare war on the king, suggesting that Lyanna may have been merely a convenient catalyst. Thus, the kidnap of Lyanna begins to look more and more like a fortuitous opportunity presented as valid just cause for waging war. It is also convenient that, as Lyanna is now dead, the real story of what happened to her is unlikely to be told, and so Robert and Ned are able to narrativise her kidnap in such a way as to render 'Robert's Rebellion' a just war.

\section{Women in literature as metaphors for war}

\footnotetext{
${ }^{26}$ Martin, (n 22) Catelyn I.

27 ibid, Eddard I and Eddard X.

${ }^{28}$ Martin et al, (n 21) The Targaryen Kings Aerys II.

${ }^{29}$ Alyssa Rosenberg, 'Men and Monsters: Rape, Myth-Making and the Rise and Fall of Nations in a Song of Ice and Fire' in Lowder, Beyond the Wall (n 2), at 17.
} 
There is a clear parallel between the 'kidnap' of Lyanna Stark and the story of Helen of Troy. ${ }^{30}$ Lyanna, like Helen is described as a reputed beauty. Helen was described as the 'face that launched a thousand ships ${ }^{31}$ and was said to be the catalyst for the Trojan war, after she was kidnapped by Paris from her husband's home and taken to Troy. Much has been written of Helen and her complicity and blame for the subsequent events. ${ }^{32}$ Feminist literary theorists note that the use of Helen's character in literature as the catalyst for the war is not unusual as it draws on the narrative tradition of women's femininity being the cause of mankind's downfall. ${ }^{33}$ Yet, in the case of conflicts, it also provides a romanticised story through which to understand the waging of a great war. Helen, whether real or metaphorical, provides a justified cause for her husband to wage war and therefore makes conflict and violence appear necessary and appropriate. In revisiting the classic story of Helen, Martin similarly renders his characters' decisions to go to war as chivalric and romantic, and in pursuit of a woman's honour, and revises this narrative trope in positioning Lyanna as the catalyst for war and the metaphor for men's honour. Yet, he also undermines it, by outlining how the powerful Northern lords have prospered since the rebellion.

Similarly, in the real world, despite grand claims that conflict is necessary to protect women, the operation of war is rarely conducted in a way that would attest to this. Despite the legal regime's call to protect women, Gardam pragmatically notes that 'there is no obvious military advantage to be gained in protecting civilians or women - in fact quite often the reverse. ${ }^{34}$ She argues that this is because, in the development of the law of armed conflict, humanitarian considerations always take second place to military ones. ${ }^{35}$ In the same way, Askin notes that 'there is little incentive for not committing sex crimes, particularly when it is against women of the opposing side during armed conflict and the harm inflicted is broad and collective, 36 because there is rarely any recrimination for doing so. The impetus for much of the women

\footnotetext{
${ }^{30}$ In return for judging Aphrodite the most beautiful goddesses, Paris, Prince of Troy was rewarded with Helen. Some accounts have her willingly leave with Paris, others state that she was kidnapped.

${ }^{31}$ Christopher Marlowe, Dr Faustus (Roma Gill Ed.) (A \& C Black 1989), Scene 12.

${ }^{32}$ Helen's own culpability in her abduction has long been debated. It is argued about it in the Iliad itself. Homer, The Iliad (EV Rieu Trans, Penguin Books 1974), at 68 and 458.

${ }^{33}$ There is a rich tradition of interpreting man's loss of innocence to Eve's behaviour. See Justin Glenn, 'Pandora and Eve: Sex as the Root of All Evil' 71 (3) The Classical World 179, at 180; George F Butler, Milton's Pandora, Eve, Sin and the Mythographic Tradition' (2005) 44 Milton Studies 153.

${ }^{34}$ Judith Gardam, 'Women and the Law of Armed Conflict: Why the Silence?' (1997) 46 International and Comparative Law Quarterly 55, at 62.

${ }^{35}$ ibid.

${ }^{36}$ Kelly Dawn Askin, Helen Durham and Tracey Gurd, 'The Jurisprudence of International War Crimes Tribunals: Securing Gender Justice for Some Survivors'in Helen Durham and Tracey Gurd (eds), Listening to the Silences: Women and War (Martinus Niijoff 2005), at 126.
} 
peace and security agenda, the Beijing Platform for Action, concluded that international humanitarian law 'is at times systematically ignored, and human rights are often violated in armed conflict, affecting the civilian population, especially women, children, the elderly, and the disabled'. ${ }^{37}$ While the UN has sought to address this gap, ${ }^{38}$ Swaine notes that international legal frameworks continue to 'be largely devoid of a gendered understanding of conflict and of the ways that women's experiences of "conflict-related" harms might differ from historic rigid and formalized regimes of regulating international crimes. ${ }^{39}$ Meanwhile, Gardam and Charlesworth write that the usual emphasis is on the suffering and heroism of men, with the 'glorification of the combatant' seen as an integral part of the culture of warfare. ${ }^{40}$ Indeed, as Enloe argues: 'When any policy approach is militarized, one of the first things that happens is that women's voices are silenced. ${ }^{41}$ Therefore, the idea that such epic tales of chivalry reflect the reality of war can be disputed. Yet the allure of such narrativisation continues to hold sway. Thus, it is important to challenge and deconstruct this seemingly 'romantic' narrative in which war is depicted as a chivalrous and just reaction of heroic and valorous men in service of women when actual women's experiences demonstrate that this is not the case.

\section{Cementing Binary Narratives: Western Masculine Military Force is Benign}

A key theme in the story is the juxtaposition of chivalry and barbarism and what it means to act honourably. Yet, even when the characters in the story grapple with war and honour, the reader understands that the characters all believe their own causes to be justified and so view their own behaviour as honourable. In the same way as Robert's chivalrous quest to rescue Lyanna is contrasted with the barbarity of the Targaryens' murder of the Starks, in

\footnotetext{
${ }^{37} 1995$ Beijing Conference on Women, 'Beijing Declaration and Platform for Action' (Fourth World Conference on Women, Beijing, China, 4-15 September 1995) UN Doc DPI/1766/Wom, at para 131. The declaration was endorsed by the Commission on the Status of Women and the UN General Assembly during its 10 and 15 year reviews on its implementation.

${ }^{38}$ In 2000, the UN adopted its first resolution on Women, Peace and Security UN Doc S/Res/1325(2000), which has been followed by further resolutions.

${ }^{39}$ Aisling Swaine, Conflict Related Violence Against Women (Cambridge University Press 2018), at 11. See also Fionnuala Ni Aolain, 'Exploring a Feminist Theory of harm in the Context of Conflicted and Post-Conflict Societies' Queen's Law Journal 35 (2009).

${ }^{40}$ Judith Gardam and Hilary Charlesworth, 'Protection of Women in Armed Conflict' (2000) 22 Human Rights Quarterly 148.

${ }^{41}$ Cynthia Enloe, The Curious Feminist: Searching for Women in a New Age of Empire (University of California Press 2004).
} 
contemporary conflict, heinous acts committed by the enemy are depicted as evil, while those of 'our' troops are often narrativised as misdemeanours or collateral damage. ${ }^{42}$

There is a further disconnect at work in ASOIAF wherein the kidnap of Lyanna by Rhaegar and the behaviour of the Targaryens is viewed by the key (male) characters as the ultimate insult against chivalry, honour and legality. ${ }^{43}$ As Robert states to Ned: 'What did any Targaryen ever know of honor? Go down into your crypt and ask Lyanna about the dragon's honor!'44 Reference to their lack of honour is used throughout the books to confirm that the Targaryens were dangerous and thus, deposing them was the 'right' thing to do. Yet, at the same time, it is clear that very few characters consider the dishonourable behaviour of Robert's forces, and in particular, the infamous murder of Rhaegar's wife and children, as problematic. ${ }^{45}$ Indeed, it is made clear that very few characters think of this at all. We are told that Ned encouraged Robert to punish the perpetrators, but Robert refused. ${ }^{46}$ We can see clearly that Ned is considered stubborn, and that his code of honour and adherence to principles often gets in the way of more pragmatic considerations. Certainly, none of the other key (male) characters share Ned's unease about the brutal and sadistic rape and murder of Elia and her children. While it was ultimately Robert's future father in law, Tywin Lannister who ordered it, Robert is entirely unrepentant. This act of barbarity is referenced throughout the books from multiple character perspectives. When pressed about his complicity in the murders, Tywin merely concedes to his son: 'I grant you it was done too brutally. ${ }^{47}$ Rosenberg notes how, when questioned about the necessity of such an act, Tywin is unrepentant about sanctioning it, but lays the blame for sadism and the rape solely with his knight Gregor Clegane, ${ }^{48}$ invoking the 'lone wolf' trope whereby violence committed by 'our' troops can never be anything but measured, proportionate or necessary. Any account of gratuitous sexual violence or brutality is therefore automatically rendered as the exception committed by a 'lone wolf' acting outside the chain of command, rather than an unpalatable truth of warfare. This trope is invoked, particularly in relation to military violence, to suggest that when extreme violence is publicised, that it is a result of one lone offender, and not a natural consequence of masculine militarised culture.

\footnotetext{
${ }^{42}$ Nicola Pratt, 'Reconceptualizing Gender, Reinscribing Racial-Sexual Boundaries in International Security: The Case of UN Security Council Resolution 1325 on "Women, Peace and Security" (2013) 57 International Studies Quarterly 772, at 777.

${ }^{43}$ Martin, (n 22), Eddard I, at 44.

44 ibid, Eddard II, at 116.

45 ibid, at 112.

46 ibid.

${ }^{47}$ George RR Martin, A Storm of Swords (Harper Voyager 2003) Tyrion VI, at 148.

${ }^{48}$ Rosenberg, (n 29), at 23.
} 
Speaking after a British marine was convicted of the murder of an injured Afghan captive, Colonel Richard Kemp stated that: 'This murder is a grotesque violation of British forces' longstanding reputation for morality and humanity even in the most desperate battlefield conditions...Execution of prisoners of war is a crime we associate with Nazi Stormtroopers, not Royal Marines. ${ }^{49}$ Distinguishing this Marine from the others, General Sir Mike Jackson, said that, it was worth bearing in mind that of the 100,000 troops who had served abroad, Marine A was the only one who had committed murder. ${ }^{50}$

Accordingly, it is not until the later books, when we are introduced to Elia's brother Oberyn, who still harbours thoughts of vengeance over the murder of his sister, niece, and nephew, that we meet another key character who views Elia's rape and murder as a heinous act with lasting consequences. When he arrives in the capital he is still brooding over the murder of his sister sixteen years previously, noting that 'Justice is in short supply this side of the mountains. There has been none for Elia, Aegon or Rhaenys. ${ }^{51}$ Yet it is made clear that the other characters find Oberyn's obsession with obtaining justice for his sister tedious and even a threat to realm's hegemony. ${ }^{52}$ The juxtaposition of Ned and Oberyn's disgust at the behaviour of Robert's forces against the nonchalant acceptance of everyone else poses a key dilemma to the reader. Having rendered the rape and murder of Elia in such a matter of fact account, then introducing Oberyn's quest for vengeance, Martin challenges the reader to re-evaluate the original account. ${ }^{53}$

This revision of the dominant narrative mirrors the feminist deconstruction of actual sexual violence in conflict, which critiques the reductive framing of sexual violence that allows it to be narrativised as behaviour only perpetrated by 'other' militaries. ${ }^{54}$ These feminist deconstructions also juxtapose the accounts of sexual violence by enemy combatants against situations where sexual violence is perpetrated by 'our' military. ${ }^{55}$ The fact that there can be

\footnotetext{
${ }^{49}$ Steven Morris and Richard Norton-Taylor, 'Marine Faces Life Term after Being Found Guilty of 'Executing' Afghan Insurgent' The Guardian (London) Fri $8^{\text {th }}$ November 2013.

50 ibid. In sentencing, HHJ Jeff Blackett, Judge Advocate General distinguished the soldier's conduct from that of others, stating that 'Hearts and minds will not be won if British service personnel act with brutality and savagery... you undermined much of the good work done day in and day out by British forces.' $R v$ Sergeant Alexander Wayne Blackman (formerly known as Marine A) 6 December 2013 (sentencing remarks of Military Court).

${ }^{51}$ Martin, (n 47) Tyrion IX, at 336.

52 ibid, Tyrion VI, at 148 .

${ }^{53}$ Frankel, (n 3), at 70-71.

${ }^{54}$ Martina E Vanderberg. 'Peacekeeping, Human Trafficking, and Sexual Abuse and Exploitation' in Ni Aolain et al, The Oxford Handbook of Gender and Conflict (Oxford University Press 2018).

${ }^{55}$ Pratt, (n 44), at 777.
} 
two distinct narratives suggest that the dominant militarised, masculine culture seems to point to an acceptance of the sexual abuse and killing of women and children by 'our' troops as an unfortunate but realistic outcome of conflict. It is seen merely as a form of collateral damage, so long as it is faceless 'other' women who are the victims. ${ }^{56}$ Or it is narrativised as a technical problem that can be managed with training or downplayed. ${ }^{57} \mathrm{~A}$ classic example of this disconnect between the differing narrativisation of sexual violence in wartime was the collective silence over the mass rape of women in Berlin when the city fell to the allied forces in World War II. As Halley notes, even the women themselves understood that as the losing side, German civilians would not be viewed as the 'innocent victims'. ${ }^{58}$ In contrast, Pratt describes how "sexual violence committed by the "brown" parties to conflict is considered a war crime'. 59

Accordingly, Martin's depiction of the indifference toward Elia's death mirrors the idea that the treatment of women is of little consequence, unless it can be used to mobilise support for war, and so female sacrifice is an unpleasant, but necessary, component of the war effort. This further cements the narrative that women are mere passive objects on whose behalf war is fought and therefore, as passive objects women should submit to the patriarchal frameworks that conflict generally imposes.

The prevalence of sexual assault and rape of women during times of conflict is testament to the fact that war is rarely in women's interests and instead serves to make them more vulnerable. ${ }^{60}$ While the kidnap and rape of Lyanna is given as the justification for a righteous

\footnotetext{
${ }^{56}$ MacKinnon describes rape during conflict as 'just something men do.' See Catharine Mackinnon, Turning Rape into Pornography: Postmodern Genocide, in Alexandra Stiglmayer and Marion Faber (eds), Mass Rape: The War against Women in Bosnia-Herzegovina (University of Nebraska Press 1994), at 80.

${ }^{57}$ A UNIFEM Report found evidence of sexual abuse and exploitation in almost every existing peacekeeping operation. See Elizabeth Rehn E and Ellen Johnson Sirleaf, 'Unifem Women, War and Peace: The Independent Experts' Assessment on the Impact of Armed Conflict on Women and Women's Role in Peace-Building' (United Nations Development Fund for Women 2002). Statistics on sexual misconduct can be found at https://conduct.unmissions.org/sea-data-introduction. In light of this, the UN has implemented a policy of zero tolerance for sexual misconduct by peacekeepers. See Antonio Guterres 'Special Measures for Protection from Sexual Exploitation and Abuse' (15 February 2018) UN Doc A/72/751; UN Security Council Resolution 2272 UN Doc S/RES/2272; General Assembly Resolutions 278 (UN Doc A/RES/71/278) and 297 (UN Doc $\mathrm{A} / \mathrm{RES} / 71 / 297)$.

${ }^{58}$ Janet Halley, 'Rape in Berlin: Reconsidering the Criminalisation of Rape in the International Law of Armed Conflict' (2008) 9 Melbourne Journal of International Law 78, at 111.

${ }^{59}$ Pratt, (n 44), at 777.

${ }^{60}$ Charlotte Lindsey-Curtet, Florence Tercier Holst-Roness and Letitia Anderson, 'Addressing the Needs of Women Affected by Armed Conflict: An ICRC Guidance Document' (International Committee of the Red Cross, 2004), at 6; See also 'Statement by Renee Guisan, Head of the ICRC Delegation to the Fourth World Conference on Women' (Beijing); Beijing Declaration and Platform for Action, para 136; UN Press Release, 'Women Suffer
} 
war in order to win back her honour, Lyanna's own experience of this is rarely taken into consideration. The violence of the alleged act itself and its impact on Lyanna appears less important than the effect this had on the men who were close to her. As Frankel notes 'Women who only affect the men with their existence are considered the weakest of characters, an example of women who have no purpose or importance in their own lives. ${ }^{61}$ Lyanna is depicted as the classic 'damsel in distress'; a young woman who is viewed as virtuous, chaste, and innocent, who lacks the agency or capacity to save herself, so much so, that critical literature scholar Karen Rowe describes her as 'impotent'. ${ }^{62}$

The continued appeal of narrativising real life wars as though they are in the service of rescuing women from sexual predators relies on women being seen as passive victims, and so perpetuates the idea that women are without agency and fulfil the role of the victims. ${ }^{63}$ The metaphor of rape, or indeed the plot device of rape, for conveying the motivations for going to war, is problematic, not only because it often romanticises the act of rape, but also because it suggests that even if we understand rape to be a heinous act, it is one that the female characters must suffer in order to advance the plot and communicate the motivations of the male characters. Gravdal describes romance in literature as "that which blurs the distinction between seduction and aggression'. ${ }^{64}$ Thus, the romanticising of the 'kidnaps' of Helen and Lyanna is in itself problematic because as Halley writes: 'rape in war is not merely either ignored and condoned or prosecuted and punished, but intrinsically problematically related to our evaluations of the badness of rape and the badness of war. ${ }^{65}$

\section{Cementing binary narratives: female sacrifice is necessary during war}

In the Greek myth, Helen's brother in law sacrificed his daughter Iphigenia to secure a favourable wind so the Greek ships could set sail for Troy and commence the war to win Helen back. ${ }^{66}$ Similarly, in ASOIAF female sacrifice is littered throughout the stories, but it is in the

\footnotetext{
Disproportionately During and After War, Security Council Told During Day Long Debate on Peace and Security' UN Doc SC/7908 (29 October 2003).

${ }^{61}$ Frankel, (n 3), at 71.

${ }^{62}$ Karen E. Rowe, 'Feminism and Fairy Tales' 6 Women's Studies: An Interdisciplinary Journal 237, at 239.

${ }^{63}$ Karen Engle is critical of the dominant rape narrative within international criminal law, which, she argues, postulates that women can only ever be victims of rape. See Karen Engle, 'Feminism and Its (Dis) Contents: Criminalizing Wartime Rape in Bosnia and Herzegovina' (1999) 99 American Journal of International Law 778; Karen Engle, 'Judging Sex in War' (2008) 106 Michigan Law Review 941.

${ }^{64}$ Kathryn Gravdal, Ravishing Maidens: Writing Rape in Medieval French Literature and Law (University of Pennsylvania Press 1991), at 14.

${ }^{65}$ Halley, (n 58), at 78.

${ }^{66}$ Robert Graves, The Greek Myths (Penguin Books 2001), at 591.
} 
television adaptation that we see this most clearly when, evoking the sacrifice of Iphigenia, Stannis Baratheon (Robert's brother) sacrifices his daughter Shireen in order to win the favour of the Red God and secure victory in battle. ${ }^{67}$ The clear message from such sacrifices is that women's identities and needs can easily be sacrificed for the 'greater good', or certainly men's needs, and because of this, such horrific acts can be re-narrativised as romantic or stoic in the severance of a righteous cause. In the Iliad, very little discussion is given to Iphigenia's death. ${ }^{68}$ Yet, unlike in the Iliad, Stannis' sacrifice of his daughter is not rewarded. Here, again, ASOIAF departs from the traditional narrative and presents the reader with the unadulterated horror of war with the inescapable conclusion that such sacrifice cannot, and should not, be narrativised as a noble or valorous act for the greater good. Burning his daughter alive was seen as needlessly horrific. Even the depiction of this act on screen outraged viewers and generated some of the most heated criticism of the show. ${ }^{69}$

Although not in the same horrific way, Lyanna is both literally and metaphorically sacrificed in the story. Indeed, in some respect, Martin presents Lyanna as even more tragic than the illfated Helen, she exists only as a memory and we learn of her fate through the words and memories of men. We never hear her speak, or see any insight into her character or motivations. She exists merely as a body on which male desire is played out and thus she is able to be narrativised as the perfect noble woman. Frankel notes that Lyanna serves a romaticised function in the story: 'She exists completely to influence the men's actions through their love for her. ${ }^{70}$ She notes how this invokes the comic book trope of "women in refrigerators' ${ }^{71}$ whereby a female character's only purpose in a story is to be brutally murdered in order for this to leave a lasting effect on the hero. Yet, while it might be argued that claims of just war in service of women's honour exists only in the imagination, it is in fact evident that just war narratives remain in popular conscience and are even re-emerging in legal consciousness. ${ }^{72}$

\footnotetext{
${ }^{67}$ Game of Thrones, Season 5 Episode 9: The Dance of Dragons (aired $7^{\text {th }}$ June 2015).

${ }^{68}$ In Euripides' version of the story, Iphigenia is a willing victim. The traditional version involves her being sacrificed against her will, although Artemis saves her at the last minute. As Sorum notes, both the rescue version and willing sacrifice version sanitise Agamemnon's barbarity and so there is little need to discuss Iphigenia's fate. See Christina Elliot Sorum, 'Myth Choice and Meaning in Euripides' Iphigenia at Aulus' (1992) The American Journal of Philology 113 (4) 527.

${ }^{69}$ Spencer Kornhaber, 'The Most Disturbing Thing About Game of Thrones' Most Disturbing Scene' The Atlantic (LA) 11 June 2015; Alice Vincent, 'George RR Martin Always Intended for Shireen to Meet her Controversial End' The Telegraph (London) 14 March 2016.

${ }^{70}$ Frankel, (n 3), at 71.

71 ibid.

${ }^{72}$ At the onset of the military intervention in Afghanistan Laura Bush declared that 'the fight against terrorism is also a fight for the rights and dignity of women. Radio Address by Mrs Laura Bush, $17^{\text {th }}$ November 2001. There is a plethora of work that critiques the depiction of the intervention as being in service of Afghan women. See for
} 
Swaine writes that "The power of the perceived chaste innocence and vulnerability of the women sexually violated by "monster" combatants means that engagement with conflictafflicted populations now entails looking for the sexual violence story. ${ }^{73}$ She references recent conflicts in Iraq and Syria, noting how those who have suffered sexual violence at the hands of ISIS are 'showcased in real-time on Internet sites, Youtube, and daily newspapers, their celebrification now an element of their maltreatment and dehumanization' ${ }^{74}$

\section{The Result: Selling War as Benevolent and Righteous}

The justification for resorting to war is often that it was the 'right' thing to do. Indeed, historically, the righteous or justness of a war was what made it legal and credible. The just war doctrine as a moral legitimation of war was first conceived by the Greeks and has much of its roots in the theory of natural law. ${ }^{75}$ Aristotle remarks that 'a war that is subject to the law of nature is a just war'. ${ }^{76}$ This was formalized by the Romans into a valid legal doctrine, although its main function remained as providing a moral legitimation for warfare. ${ }^{77}$ Early Christian writers used the theory of just war to forge a compromise between the Christian tradition that viewed war as immoral, and the pragmatic needs of medieval peoples to wage war. These ideas were then substantiated and codified by Thomas Aquinas in his Summa Theologiae ${ }^{78}$ which in turn influenced the modern understanding of just war. ${ }^{79}$ Despite the waning influence of natural law during the Enlightenment, the just war doctrine as conceptualised by Aquinas lingered and was incorporated into international law by Grotius. ${ }^{80}$ His seminal work De Jure Belli ac Pacis provided the first modern account of the just war

example: Lila Abu-Lughod, 'Do Muslim Women Really Need Saving? Anthropological Reflections on Cultural Relativism and Its Others' (2002) 104 American Anthropologist 783; LJ Shepherd, 'Veiled References: Constructions of Gender in the Bush Administration Discourse on the Attacks on Afghanistan Post-9/11' (2006) 8 International Feminist Journal of Politics 19; Sunera Thobani, 'White Wars: White Feminisms and the "War on Terror"' (2007) 8 Feminist Theory 169; Karen Engle, 'Liberal Internationalism, Feminism, and the Suppression of Critique: Contemporary Approaches to Global Order in the United States' 46 Harvard International Law Journal 427; Vesuki Nesiah, 'From Berlin to Bonn to Baghdad: A Space for Infinite Justice' 17 Harvard Human Rights Jouranal 75.

${ }^{73}$ Swaine, (n 39), at 38.

74 ibid. See also Myrttinen and Swaine, (n 19).

75 Simon Chesterman, Just War or Just Peace?: Humanitarian Intervention and International Law (Oxford University Press 2001).

${ }^{76}$ Aristotle, The Politics (Trevor J. Saunders ed, T Sinclair tr, Penguin Books 1981), at 3.

77 ibid.

${ }^{78}$ William Benton, The Summa Theologica of Saint Thomas Aquinas (University of Chicago 1952).

${ }^{79}$ Chesterman, (n 75).

${ }^{80}$ See Joachim Von Elbe, 'The Evolution of the Concept of the Just War in International Law' (1939) 33 The American Journal of International Law 665. 
doctrine in international $\mathrm{law}^{81}$ and it remained a major influence on Western jurisprudence well into the twentieth century. ${ }^{82}$ Grotius reasoned that a war was just if it was fought in order to protect people or to fight evil. ${ }^{83}$

Thus, even the carefully reasoned opinions of Grotius, which offered much more restraint and respect for legal reasoning, still drew on just war notions rooted in subjectivity. Indeed, it is difficult to conceive of a just war doctrine that is not entirely subjective, leading Douzinas to describe it as one of the 'hardest moral mazes' ${ }^{84}$ It was therefore this inability of international law to define objective requirements by which a just war could be judged that led in part to its abandonment as a legal principle. ${ }^{85}$ This, coupled with the rise of legal positivism and the sanctifying of state sovereignty, meant a departure from invoking morality as a legitimating standard. Instead international law recognised the absolute power of sovereign states and with it the idea that they could determine their own justifications for going to war, which no longer had to be just. ${ }^{86}$

However, whilst it could be claimed that just war theory was abandoned by legal scholars in favour of positivistic justifications for war, the moral ideology of the just war tradition endures and is enjoying a revival. Chesterman argues that the moral ideology of waging war to protect the innocent has remained and has influenced the creation of the of Responsibility to Protect doctrine. ${ }^{87}$ Tsagourias argues that the requirements for humanitarian intervention are merely 'refinements of the just war theory. ${ }^{88}$ In discussing the issues with this humanitarian justification for war, Chinkin and Kaldor note that 'humanitarianism provides the smokescreen for a neo-conservative ideology'89 which reinforces 'the binary distinction of protector/protected, casting the latter as victims and lacking agency. ${ }^{90}$ Similarly, Dexter writes

\footnotetext{
${ }^{81}$ Hugo Grotius, The Law of War and Peace: De Jure Belli Ac Pacis Libri Tres (Francis W. Kelsey and Arthur E.R Boak trs) (Bobbs-Merrill 1962).

${ }^{82}$ Chesterman, (n 75).

${ }^{83}$ Stephen Neff, Hugo Grotius on the Law of War and Peace Student Edition (Cambridge Books Online), at 285.

${ }^{84}$ Costas Douzinas, 'Postmodern Just Wars: Kosovo, Afghanistan and the New World Order' in J. Strawson (ed), Law after Ground Zero (Routledge Cavendish 2002).

${ }^{85}$ Chesterman, (n 75).

${ }^{86}$ Christian Wolff is credited with being the first to distinguish between positivist international law and natural law. He is followed by Vattel who likewise rejects Grotius' endorsement of just law theory. See ibid.

${ }^{87}$ Stephen C. Neff, War and the Law of Nations: A General History (Cambridge University Press 2005).

${ }^{88}$ Nikolaos K. Tsagourias, Jurisprudence of International Law: The Humanitarian Dimension (Manchester University Press 2000), at 73.

${ }^{89}$ Christine Chinkin and Mary Kaldor, International Law and New Wars (Cambridge University Press 2017), at 218.

90 ibid.
} 
that 'war is no longer the prerogative of international criminals, but the first resort of the righteous. ${ }^{91}$ This lays the foundations for a wider heroic narrative to take root, which positions Western militarism as just and righteous, and in service of oppressed victims. So dominant is this narrative that, as a result, all Western military action can be seen as in the service of good. ${ }^{92}$

The invocation of Manichean tropes of good versus evil, and civilisation versus barbarism ingrain the dominant narrative that war is a tool of liberation that visits no harm on innocent civilians and instead can be depicted as noble, necessary, and honourable. ${ }^{93}$ Yet, the problem with a just war narrative that presumes to protect women through juxtaposing the enemy's illtreatment of women, is that it actually blames women, and so, rather than being protectionist or emancipatory, it is actually deeply patriarchal and misogynistic. ${ }^{94}$ For example, Morgan describes how in narrativising war as a chivalrous endeavour to protect women can cement gendered stereotypes and roles of women. She notes how women in long-standing conflicts are expected to compliantly produce the next generation of male fighters. ${ }^{95}$ Any attempt by the women to take control of their bodies and reproductive rights is seen as selfish and undermining the cause. ${ }^{96}$ This is because 'an attack on the war is an attack on the nation. ${ }^{97}$ Morgan highlights that women's rights are seen as worth sacrificing for the greater good, and so patriarchal systems must be rigidly maintained. ${ }^{98}$ Furthermore, long term conflict often results in the acceptance of masculine militarised culture which is linked to increased incidents of 'everyday' violence against women. ${ }^{99}$ Women who suffer discrimination during peacetime experience it to a much greater extent during conflict, ${ }^{100}$ leading Bennoune to assert that 'violence against women in armed conflict should be understood; as a (perhaps gross) magnification of "ordinary" violence and attitudes.' 101

\footnotetext{
${ }^{91}$ Helen Dexter, 'The "New War"on Terror, Cosmopolitanism and the "Just War" Revival' (2008) 43 Government and Opposition 55, at 58.

${ }^{92}$ Chandler, (n 24).

${ }^{93}$ Lynsey Mitchell, 'Monsters, Martyrs, Heroes and their Storytellers: The Enduring Attraction of Culturally Embedded Narratives in the "War on Terror"” (2014) 35 (1) Liverpool Law Review 83.

${ }^{94}$ Iris Marion Young, 'The Logic of Masculinist Protection: Reflections on the Current Security State' (2003) 29 Signs 1; Shepherd, (n 72).

${ }^{95}$ Robin Morgan, The Demon Lover: On the Sexuality of Terrorism (Piatkus 2001).

96 ibid.

${ }^{97}$ Kesic, (n 16), at 190.

${ }^{98}$ Morgan, (n 95).

99 Alicia Elaine Luedke and Hannah Faye Logan, “"That Thing of Human Rights": Discourse, Emergency Assistance, and Sexual Violence in South Sudan's Current Civil War' 2018 42(1) S99.

${ }^{100}$ Marie Vlachova, Women in an Insecure World (Emerald Group Publishing Limited 2006).

${ }^{101}$ Karima Bennoune, 'Do We Need New International Law to Protect Women in Armed Conflict' (2006) 38 Case Western Reserve Journal of International Law 363, at 370.
} 


\section{The result: women without agency}

The final consequence of deploying this rescue narrative as a justification of war, is that it perpetuates a portrayal of women as one-dimensional characters without agency, which feeds heavily into gendered constructions of women as victims in need of protection bestowed by powerful men. ${ }^{102}$ Buchanan and Johnstone write that the rescue narrative of military intervention is central to the Anglo/American legal tradition ${ }^{103}$ and demonstrate how the American frontier, or western, narrative serves as a metaphor for a strong US state protecting women and children from the uncivilised 'other'. ${ }^{104}$ Indeed, Mead argues that the western is America's founding myth, which needs to be continually retold. ${ }^{105}$ Yet, this continued reenacting of frontier mythology likewise ensures that women continue to be cast as silent victims because women in these stories rarely exist as characters in their own right. ${ }^{106}$ Instead they become an empty vessel into which others can pour their own desires and understandings, creating a perfect idealised version of femininity.

Thus, passive, helpless, oppressed women not only serve as the perfect legitimation for military force, they are necessary to legitimise military force. It is well established that even protectionist language that purports to engage with women is often still grounded in patriarchal assumptions over women's roles and anxiety about their sexuality. ${ }^{107}$ Heathcote asserts that: 'production of a restrictive female sexuality, vulnerable to attack from rogue male actors, is a reiteration of the sexed and gendered discourse which was prevalent in security discourse prior to the global war on terrorism.' ${ }^{108}$ Indeed, in the run up to the West's military intervention in Afghanistan in 2001, the continued depiction of Afghan women as helpless, oppressed victims suggests that that the West felt more comfortable viewing them as passive objects who could not speak for themselves, evoking Mohanty's observations that Third World women can be

\footnotetext{
${ }^{102}$ Krista Hunt, 'The Strategic Co-Optation of Women's Rights' (2002) 4 International Feminist Journal of Politics 116, at 117.

${ }^{103}$ Ruth Buchanan and Rebecca Johnson, 'The Unforgiven Sources of International Law: Nation-Building, Violence, and Gender in the West (Ern)' in Doris Buss and Ambreena Manji (eds), International Law: Modern Feminist Approaches (Hart 2005).

${ }^{104}$ President Bush was frequently depicted in frontier 'folkisms' as the archetypical western sheriff protecting America from outlaws. See Stacy Takacs, 'The Contemporary Politics of the Western Form: Bush, Saving Jessica Lynch and Deadwood' in Jeff Birkenstein, Anna Froula and Karen Randell (eds), Reframing 9/11: Film, Popular Culture and the "War on Terror" (Continuum 2010), at 153.

${ }^{105}$ John Mead, 'Manhood, Mourning and the American Romance', in Birkenstein, Froula and Randell (eds), Reframing 9/11: Film, Popular Culture and the "War on Terror".

${ }^{106}$ ibid.

${ }^{107}$ Halley, (n 58).

${ }^{108}$ Gina Heathcote, 'Feminist Reflections on the End of the War on Terror' (2010) 11 Melbourne Journal of International Law, at 20.
} 
depicted as having 'needs and wants' but never solutions, choices or agency. ${ }^{109}$ Similarly, commenting on the failure of the West to engage with ordinary Afghan women as actors following the intervention, and the prevalence of images of burqa clad, victimised women in Western media, Kolhatkar observed 'what good is it to flaunt images of Afghan women marching militantly with fists in the air, carrying banners about freedom, democracy and secular government? These women wouldn't need saving.' 110

Such stereotyping of victims as silent and helpless is so ingrained that it applies not just to women, but as a feminising of all victims whose plight is used to justify military action, leading Koskenniemi to conclude that the 'Kosovo Albanian is worthy of humanitarian support as long as he remains a helpless victim - but turns into a danger the moment he seeks to liberate himself.' 111 Accordingly, Heathcote notes that 'the authorisation of the use of force for the protection of civilians ignores the agency of local communities, economic capacities and vulnerabilities, as well as the risks force bring to communities.' ${ }^{112}$

Thus, rather than the silencing of women being an unfortunate and unintended consequence of this narrative, it appears in fact that silencing women and reducing them to passive objects is in fact instrumental to its operation.

\section{The Subversive Potential of Lyanna Stark? Understanding the Turn to Militarism Not as a Chivalrous or Altruistic Response}

Initially, it is easy to suggest that Lyanna Stark is the ultimate stereotype of a woman without agency, given narrative form only to further the plot and demonstrate the motivations for men to go to war, and render them chivalrous and heroic. Yet, hidden in the subtext is the possibility that the narrative presented is only that. It is strongly hinted that Lyanna was not kidnapped or raped, but that she and Rhaegar had eloped and continued a consensual relationship. ${ }^{113}$ The reader learns from a stand-alone book that following 'Robert's Rebellion', Ned arrived at the

${ }^{109}$ Chandra Mohanty, 'Under Western Eyes: Feminist Scholarship and Colonial Discourses' (1988) Feminist Review 61, at 72.

${ }^{110}$ Sonali Kolhatkar, “'Saving” Afghan Women' 〈http://www.rawa.org/znet.htm>.

${ }^{111}$ Martti Koskenniemi, “"The Lady Doth Protest Too Much" Kosovo, and the Turn to Ethics in International Law' (2002) 65 The Modern Law Review 159, at 173.

${ }^{112}$ Gina Heathcote, 'Women and Children and Elephants as Justification for Force' (2017) 4 (1) Journal on the Use of Force and international Law 66.

${ }^{113}$ This long-suspected twist has been further interrogated by the television series which has now overtaken the books. 
Tower of Joy with six of his men and found Lyanna dying in childbirth. ${ }^{114}$ Lyanna extracted a promise from her brother, but it is never confirmed to the reader what this promise is, although it is presumed that he agreed to claim her and Rhaegar's son as his own in order to hide the child from Robert. For the many readers who have engaged in a thorough textual analysis of Martin's works, it is clear that the official narrative of the kidnap and rape of Lyanna does not add up. Instead it becomes clear that this narrative is the one that suits those who won the war. Antonsson and Garcia note that after her death Lyanna is romanticised and mythologised by Robert despite that fact that he barely knew her. ${ }^{115}$ This romantic nostalgia also forces him to view her death as the consequence of a malevolent kidnap. The fact that Lyanna may have loved Rhaegar and run off willingly is never interrogated. Yet, it is odd that Lyanna's brother, who was able to speak with her as she lay dying and so clearly knew the truth of the matter, should promote Robert's tragic narrative. However, if Ned knows that Lyanna was not kidnapped, it renders the entire war, especially the death of his father and brother entirely in vain. As Bran remarks in the TV show: 'Robert's war was fought on a lie'. ${ }^{116}$ Removing the chivalrous and just pretention that the war was about rescuing Lyanna casts it as merely a power grab by a man who is just a ruthless and ambitious as those he deposed.

Throughout the novels so far, the key (male) characters have given their descriptions and recollections of the war, and their motives for joining the fight. These men ascribe romantic and righteous motives for their aggressive behaviour, and so excuse their own violent treatment of women. Yet, the revelations of Lyanna's part in the story serve to render the war pointless if fought only for righteous or chivalric notions, especially given they did not save her. Instead it is revealed as a more mundane fight over land, power and wealth.

In the same way, this narrative of promoting war as necessary and in service of women is one that endures today. Much like Martin's romantic narrative of Lyanna, there is a tendency to assume that because military action is narrativised as chivalrous and benign, that this then somehow renders all acts of war as chivalrous and benign, when indeed the opposite is often true. ${ }^{117}$ For example, despite the rhetoric that sought to justify the 'War on Terror' as a war for

\footnotetext{
${ }^{114}$ Martin, Garcia, and Antonsson, (n 21).

${ }^{115}$ Linda Antonsson and Elio M. Garcia, 'The Palace of Love, the Palace of Sorrow: Romanticism in a Song of Ice and Fire' in Lowder, Beyond the Wall, (n 2), at 4.

${ }^{116}$ Game of Thrones Season 7, Episode 7: The Dragon and the Wolf (aired 27 August 2017).

${ }^{117}$ Chinkin and Kaldor, (n 89).
} 
women's rights, ${ }^{118}$ the irony was that while American women supported the offensive, Afghan women protested the bombing and called on their American sisters to prevent it. ${ }^{119}$ These protestations were ignored because, as Delphy argues, 'it is better for them to die from bombs, from hunger, from cold, than to live under the Taliban. Death from servitude: that is what Western public opinion has decided for Afghan women. ${ }^{120}$ Yet, while the women's needs and wants were ignored, their image as victims were used to legitimate the action. ${ }^{121}$ However, this entrenching of women in the role of victims further reduces their capacity to have agency. If the treatment of women during conflict, especially sexual violence, is to be challenged then there is a need to acknowledge, firstly, that gendered violence is often the reality of war. The prevalence of such behaviour should not be mitigated by the invocation of chivalry or heroicism which postulates military force as a benign instrument in service of women.

\section{Conclusion}

The article has argued that the story told in ASOIAF, which situates the kidnap of Lyanna Stark as the impetus for 'Robert's Rebellion', has offered a useful lens through which to explore the contemporary use of 'saving women' as justification for war, and the problematic nature of such justificatory narratives in that they perpetuate regressive stereotypes of women as passive victims. Additionally, in the same way as the tragic story of the quest to save Lyanna disguises 'Robert's Rebellion' as a noble and just cause, unfettered acceptance of this heroic narrative as a justification for actual wars occludes rational assessment of the merits and consequences of war, which is often increased hardship for women, and in particular, increased threat of sexual violence.

The eventual knowledge that Lyanna was not forcibly kidnapped and raped, but instead chose to elope with Rhaegar, and in fact married him, demonstrates that the indignation directed toward the Targaryens, and the call to arms to restore Lyanna's honour, was not in fact for the

\footnotetext{
${ }^{118}$ Prior to the military offensive in Afghanistan, the Bush Administration released a report alongside depictions of Afghan women forced to wear the burqa, which saturated US and UK media. US Government 'Report on the Taliban's War Against Women' (Bureau of Democracy, Human Rights and Labor, United States of America, Washington DC 17 November 2001). Editorial, 'Liberating the Women of Afghanistan', New York Times (New York 24 November 2001).

${ }^{119}$ Cynthia Peters, 'What Does Feminism Have to Say?' in Susan Hawthorne and Bronwyn Winter (eds), After Shock: September 11, 2001 Global Feminist Perspectives (Raincast Books 2003); WLUML, 'Statement on the Attacks in the USA' in Susan Hawthorne and Bronwyn Winter (eds), After Shock: September 11, 2001 Global Feminist Perspectives.

${ }^{120}$ Christine Delphy, 'A War for Afghan Women?' in Susan Hawthorne and Bronwyn Winter (eds), After Shock: September 11, (n 119), at 339.

${ }^{121}$ See Kesic, (n 16); Morgan, (n 95).
} 
benefit of Lyanna herself. In the same way, despite the gendered protestations that war is a chivalrous endeavour, and can be used as a tool to pursue women's liberation, the reality is that the key aims of war are rarely to promote gender equality, and that the needs and wants of individual women are often deprioritised. As Heathcote notes:

The sexual violence resolutions and the women, peace and security framework ultimately do not prioritise gender equality, gender perspectives or even women's rights; rather they exist to enhance the work of the Security Council as an international institution with the capacity to authorise the use of military force. ${ }^{122}$

Such critical scholarship reminds us that war is rarely good for women, highlighting that legislative responses, even those that pertain to be in service of women's rights, such as UNSC Resolution $1325^{123}$ not only serve to normalise war and the masculinist protection paradigm, ${ }^{124}$ but also normalise 'the same radicalised and sexualized hierarchies' that underpin war ${ }^{125}$ and so perpetrate the view that war is good, ignoring the fact that war is often a contributory cause of women's oppression rather than the solution.

Thus, the example of Lyanna Stark re-scripting the narrative that the war was for her benefit, and redeemed her honour, serves as a helpful metaphor in how to rethink the pervasive narratives abounding that war can be harnessed in service of women. ${ }^{126}$ The deconstruction of Robert and Ned's motives and the removal of the romantic and chivalrous tropes force the reader to re-evaluate the allure of war. In retelling the story of the passive kidnapped woman, as opportunistic propaganda for male ambition, Martin forces the reader to pause and consider whether subjective claims as to just war are little more than mere rhetoric. The reader is then forced to grapple with the reality of narrativising war, which is often that there is justification and motive on both sides that cannot be simply framed as good versus evil.

\footnotetext{
${ }^{122}$ Heathcote, (n 112), at 83.

123 Sexual exploitation coupled with high levels of domestic violence in and around military bases is not adequately addressed in the UN's WPS agenda. See Gina Heathcote, 'Feminist Politics and the Use of Force: Theorising Feminist Action and Security Council Resolution 1325' (2011) 7 Socio-Legal Rev 23.

${ }^{124}$ Pratt, (n 55), at 777.

125 ibid, at 779.

${ }^{126}$ See Chinkin and Kaldor, (n 89), who posit a human security model that would mean focussing on the needs of civilians. They concede that it is necessary to first break the spell which ensures that western military intervention is seen as protectionist.
} 
Similarly, by highlighting how Lyanna's experience was co-opted by those who may have had ulterior motives, we can see that the framing of women only as passive and vulnerable, without allowing them to speak for themselves and become active participants in conflict decision making, ultimately allows women to be silenced and renders their actual experience of war and conflict invisible. Feminist scholars have been critical of the implicit stereotyping of women as passive victims through law's use of language, which positions women solely as victims. ${ }^{127}$ Having outlined this alternative narrativisation of war, that is easily applicable in the legal arena, this article calls for a deeper engagement with women as actors in war and not just passive victims, and also seeks to disrupt the dominant hegemony of war being understood as a chivalrous fight in protection of 'our' women. ${ }^{128}$

Ultimately, if Lyanna's narrative can be rewritten, even from beyond the grave, then it challenges the narrative put forward by the victors which justifies their behaviour. Indeed, the ability to shrug off this narrative and engage with more complex realities will allow us to view war and conflict in a more nuanced manner, disrupting this narrative by engaging with the actual women we are claiming to save. It is hoped that by giving voice to their experiences and, in particular, their opposition to military intervention, that a more holistic understanding of conflict can emerge.

\footnotetext{
${ }^{127}$ Dianne Otto, 'Lost in Translation: Re-Scripting the Sexed Subjects of International Human Rights Law' in Anne Orford (ed) International Law and Its Others (2006) at 318; Engle 1999, (n 63); Engle 2008, (n 63); Vanessa Munro and Jane Scoular, 'Abusing Vulnerability? Contemporary Law and Policy Responses to Sex Work in the UK’ (2012) 20 Feminist Legal Studies 189.

${ }^{128}$ Buchanan and Johnson, (n 103).
} 